\title{
A High Rated Solar Water Distillation Unit for Solar Homes
}

\author{
Abhishek Saxena ${ }^{1}$ and Navneet Deval ${ }^{2}$ \\ ${ }^{1}$ Mechanical Engineering Department, Moradabad Institute of Technology, Moradabad 244001, India \\ ${ }^{2}$ Mechanical Engineering Department, Meerut Institute of Engineering and Technology, Meerut 250001, India
}

Correspondence should be addressed to Abhishek Saxena; culturebeat94@yahoo.com

Received 10 September 2015; Revised 4 February 2016; Accepted 11 February 2016

Academic Editor: Abdullah A. Kendoush

Copyright (c) 2016 A. Saxena and N. Deval. This is an open access article distributed under the Creative Commons Attribution License, which permits unrestricted use, distribution, and reproduction in any medium, provided the original work is properly cited.

\begin{abstract}
India is presently focusing on complete utilization of solar energy and saving fossil fuels, which are limited. Various solar energy systems like solar cookers, solar water heaters, solar lanterns, solar PV lights, and solar lamps are continuously availing by the people of India at a low cost and on good subsidies. Apart from this, India is a solar energy promising country with a good number of solar homes (carrying solar energy systems) in its various locations. The present paper focuses on a unique combination of solar dish cooker (SDC) and solar water heater (SWH) to produce distilled water with a high distillate and a high daily productivity. The procedure has been discussed on the basis of experimental testing to produce distilled water by combining an evacuated type SWH and a SDC. Experimentation has been carried out in MIT, Moradabad (longitude, $28.83^{\circ} \mathrm{N}$, and latitude, $78.78^{\circ} \mathrm{E}$ ) by developing the same experimental setup on behalf of solar homes. The daily productivity of distilled water was found around 3.66 litres per day in full sunshine hours for an approximated $\mathrm{pH}$ value of 7.7 and a ppm value of 21 . The payback period (PBP) has been estimated around 1.16 years of the present system.
\end{abstract}

\section{Introduction}

It is well known that the water is available in a huge amount and imperative ingredient in nature. It is the major constituent of life of all creatures as well as for vegetation and sanitation. The daily demand of the fresh water is increasing day by day and seems to be increased with time (worldwide) [1]. Many countries like India, USA, UK, and China have already taken some good initiatives (by promoting solar energy) to fulfill the various demands of our routine life such as cooking, water heating, space heating and cooling, drying, distillation, and power generation [2]. India is promoting solar energy products by introducing various solar promotion schemes such as Jawaharlal Nehru Solar Mission (JLNSM2010). Under this scheme, the government of India has installed many solar projects at a low cost (like solar energy parks, PV rooftop systems, and solar lanterns) at various locations in India for a green environment and to save fossil fuels [3].

The present paper focuses on a unique combination of a SDC and SWH to produce distilled water with a high rate of distillation and productivity. About the solar still, it is used to obtain the distilled water and occupies a large space for a higher productivity. Solar stills are simple in "design and construction" and can be easily defined as a transparent glass cover (glazing) enclosing an insulated cabinet of saline/brackish water; this structure heats up the water for evaporation and then condenses on the innermost face of transparent glazing at a fixed slope angle (Figure 1) [4]. The transformed distilled water is usually potable and the quality of this distillate is too high because all the impurities in the form of salts, inorganic and organic components, and so forth are left behind in the immersion. In the presence of solar irradiance, the temperature of the water rises adequately to exterminate all types of bacteria. A thin layer of slush is expected to be cultivated in the bottom of the cabinet and later on this could be flushed as necessitated. The solar still's productivity and efficiency majorly depend on both the ambient parameters and design parameters like solar irradiance, ambient temperature, basin water depth, glazing material, thickness of the cabinet, system's orientation, type of insulation, leakage, wind velocity, thermal heat storage (if any), and the heat capacity [5]. 


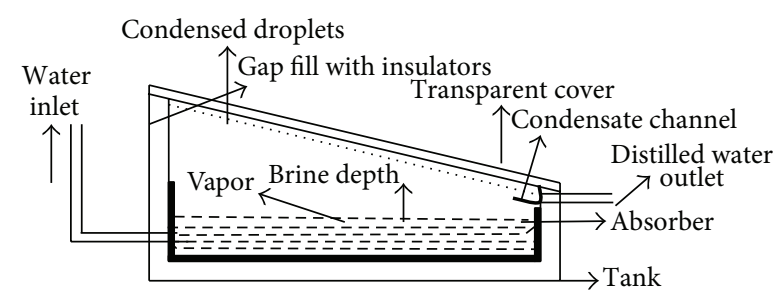

FIGURE 1: Schematic diagram of a conventional type single slope solar still.

The objective of the present research work is to utilize the ideal timings of the solar energy systems like solar water heater or air heater, which are less used in summer season. For this purpose, a survey has been carried out in a village named Pasiyapara in district Moradabad. The efforts have been made to utilize solar energy systems in ideal their timings (when the systems are not in use) to produce distilled water with a high productivity. About this particular, the village "Pasiyapara" (Maanpur, which is $35 \mathrm{~km}$ away from Moradabad city) in district Moradabad (India) has been chosen because of locating a good number of solar homes. Villagers used the solar energy systems (regularly) such as solar cookers, solar water heaters, solar lanterns, and domestic lights, because of a shortage of electricity (i.e., $8-10 \mathrm{Hrs}$ in a cycle of $24 \mathrm{Hrs}$ ). As per survey of the particular area it has been found that there is an actual shortage of electricity supply in particular region.

In this village, around 71 families are living. And for the experimentation, total five (05) families have been selected randomly, which have both the solar dish cookers (SDC) and solar water heaters (evacuated tube type) for their daily cooking and hot water needs. It has also been found that both the systems have been purchased from NEDA, Moradabad, through a subsidy in 2013, by all the families under the scheme of promotion of solar energy (i.e., JLNSM-2010). The survey has been carried out for the daily utilization of both the systems (cooker and water heater) with the help of a questionnaire (see the Appendix). After that, it has been observed that the SDC is utilized (maximum) round the year, while SWH is used less in summers in comparison of SDC (by all considered households). Apart from this, it was also notable that the SDC is used to cook the lunch only in winters, while in the summers one eatable is also cooked for dinner according to the need or climatic conditions. On the other side, the SWH is continued in use all the time in winters and in rainy season. But it is less used in summers (comparatively) because the hot water demand is quite low in summers.

It is also remarkable that almost households use a battery operated inverter to overcome the lighting problems occurring in shortage of electricity. Not only this but also nearby medication centres/dispensaries and schools often used a battery operated invertor to overcome the likely problems. It is also noteworthy that a lead acid battery or dry cell battery (generally used in automobiles or invertors) requires distilled water for uninterrupted power supply or to store

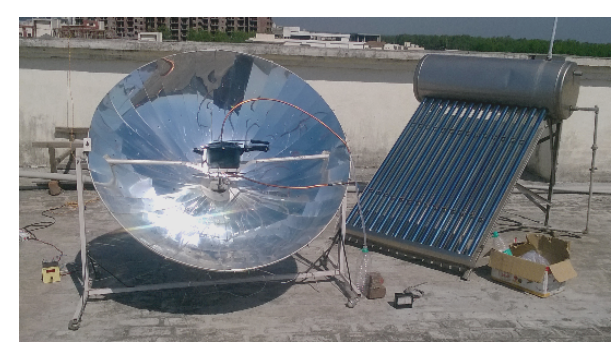

Figure 2: Experimental setup of high rated solar distilled unit.

the power backup [6]. The people of the particular area usually purchased distilled water from the nearby town or city. Therefore, to save the time spent on purchasing of the distilled water from the market and to save the money as well as a complete utilization of solar energy equipment, this concept has been generated to develop a high rated distilled water unit to fulfill the demand of distilled water (in the whole area) by utilizing the solar energy systems in their ideal timings in solar homes. It is also notable that this modification has been done at a negligible price. By developing likely units, one can eliminate the use of a solar still, occupying a large space for operation and requiring more maintenance [5]. For a reference to previous work, Table 1 [717] shows some quality contribution by pioneers of the field. But none of them has made or developed such type of high distilled water unit at negligible cost.

\section{Materials and Methods}

An experimental setup has been developed by combining the SDC and SWH on the rooftops of all the households (families). The same setup has been developed on the rooftop of H-block at Moradabad Institute of Technology, Moradabad (MIT, Moradabad) for experimentation. This research (experimental study) has been carried out for the particular Moradabad region, in which MIT, Moradabad, has been considered as a platform for conducting all the experiments because of easy availability of research apparatus and equipment. For this, both the systems (an SDC and a SWH) have been installed properly on the rooftop of Mechanical Engineering Department (H-block) in the institution. The tank capacity of SWH was 300 litres, while the hot water storage capacity was 100 litres (this was same in all cases). A 02-meter long pipe (head) was installed over the storage tank for overflow of the supply water. The original experimental setup and schematic diagram have been shown in Figures 2 and 3 , respectively.

However on the other hand a SDC was used for boiling/pasteurization of water to produce steam/vapor for distillation. The diameter of the concentrating dish was around 1.4 meters, focal length was 0.28 meters, and delivering power output was around $0.6 \mathrm{~kW}$.

The tracking of the SDC was done manually and the system was found feasible for boiling of 02- to 03-litre water within 30 minutes in a 05 -litre capacity pressure cooker. About experimentation, both the systems have been tested 


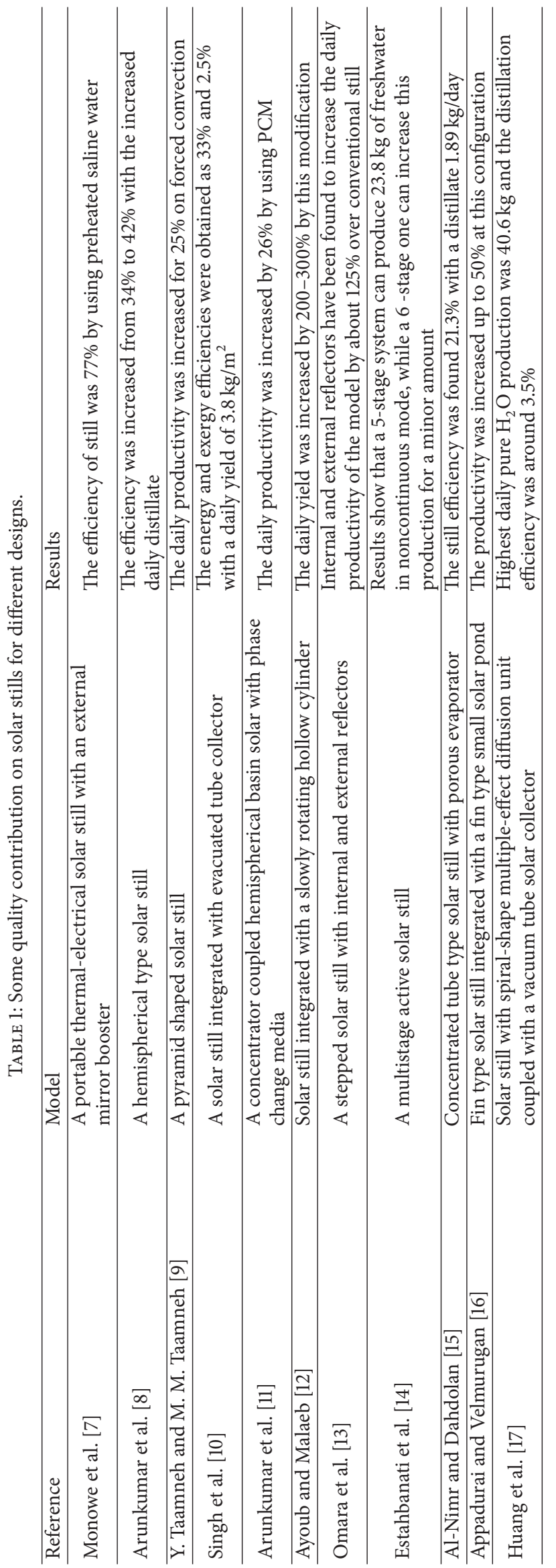




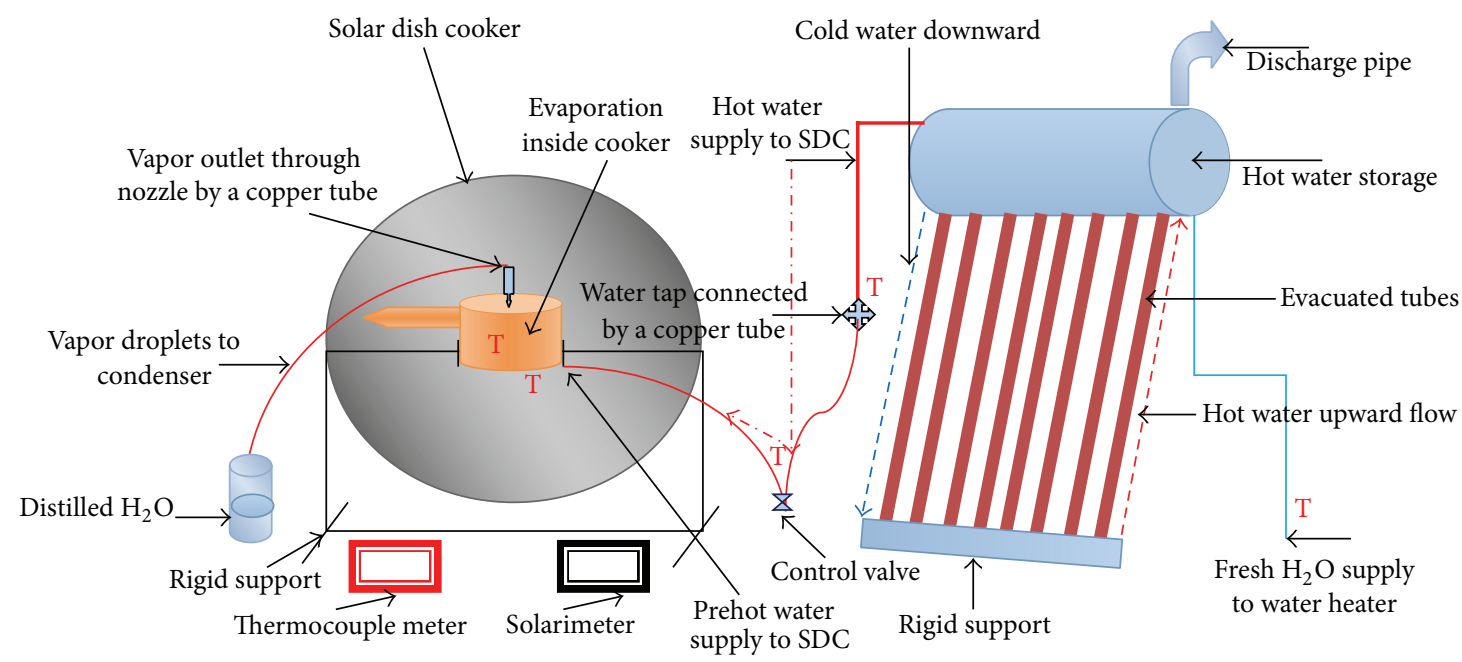

FIGURE 3: Schematic diagram of a high rated solar distilling unit; "T" is denoting the locations of thermocouple sensors, which were placed to measure the temperature variations at different positions.

to calculate their thermal efficiencies in normal ambient conditions (at summers). For experimental testing, a digital thermocouple meter with six sensors (accuracy $\pm 0.01^{\circ} \mathrm{C}$ ) has been used for the temperature measurement, an anemometer (accuracy $+0.01 \mathrm{~m} / \mathrm{s}$ ) is used to measure wind velocity, and a solarimeter "Suryamapi" (accuracy $\pm 0.01 \mathrm{~W} / \mathrm{m}^{2}$ ) has been used to measure the solar irradiance. A TDS meter (accuracy $\pm 0.1 \mathrm{pH}$ ) Milwauke $^{\mathrm{TM}}(\mathrm{pH} 600$ ) has been used to measure the $\mathrm{pH}$ value of obtained distilled water. However, a one-litre beaker was used to measure the quantity of obtained distilled water.

Apart from this, the consumption of some common fuels (depends upon the class of the household) like LPG, electricity, kerosene, fuel-wood, and coal has been assessed to estimate the net savings and to calculate the payback period (PBP) of the present system. The $\eta_{\text {therm }}$ of SDC $\left(\eta_{\text {sdc }}=59.41 \%\right)$ and $\operatorname{SWH}\left(\eta_{\mathrm{swh}}=67.57 \%\right)$ has been obtained by using (1) from reference $[18,19]$ and has a good agreement with the values recommended by the supplier [20] (according to climatic conditions):

$$
\eta_{\text {therm }}=\frac{m C_{p} \Delta T}{A \cdot I \cdot \Delta t}
$$

Net saving of conventional fuels has been calculated simply by consumption of the fuel to produce one litre of distilled water in a particular time (Table 2). The payback period has been estimated by using [18]

$$
\begin{aligned}
& N \\
& =\frac{\log [(E-M) /(a-b)]-\log [(E-M) /(a-b)-C]}{\log [(1+a) /(1+b)]},
\end{aligned}
$$

where $a$ is compound interest rate per annum (9\%), $b$ is inflation rate in energy and maintenance per annum (8\%), $C$ is cost of the unit, $E$ stands for energy savings per year, $M$ is
TABLE 2: Uncertainty of some major parameters.

\begin{tabular}{lcc}
\hline S number & Parameters & Uncertainty \\
\hline 1 & $I$ & $\pm 2.91 \mathrm{~W} / \mathrm{m}^{2}$ \\
2 & $T_{\mathrm{amb}}$ & $\pm 0.41^{\circ} \mathrm{C}$ \\
3 & $T_{\mathrm{sdc}}$ & $\pm 1.61^{\circ} \mathrm{C}$ \\
4 & $T_{\mathrm{swh}}$ & $\pm 0.11^{\circ} \mathrm{C}$ \\
5 & $\eta_{\mathrm{sdc}}$ & $0.81 \%$ \\
6 & $\eta_{\text {swh }}$ & $0.89 \%$ \\
\hline [: solar irradiance: $T_{\text {s }} \cdot$ temperature of water inside SDC $: T \cdot$ temperature
\end{tabular}

[I: solar irradiance; $T_{\text {sdc }}$ : temperature of water inside SDC; $T_{\text {swh }}$ : temperature of water inside SWH; $T_{\mathrm{amb}}$ : ambient temperature; $\eta_{\mathrm{sdc}}$ : efficiency of SDC; $\eta_{\text {swh }}$ : efficiency of SWH].

maintenance cost per annum (2\%), and $N$ stands for payback periods.

With the help of the questionnaire (see the Appendix), it became easy to find the ideal timings (when the systems are not in use) of SDC and SWH for considered solar homes. The experimentation has been started at 10:00 hrs in the morning and finished at 18:00 hrs in the evening. Reading has been taken for the temperature variations in water and ambient conditions as well as for solar irradiance. All measuring devices have been properly checked for their accuracy before experimentation.

\section{Result and Discussion}

The experimental setup of distillation unit has been developed by combining a SDC (cooking one meal at a time) and a SWH (100 ltrs/day of hot water) and the present distillation unit was installed on the rooftop of MIT, Moradabad. It is notable that $\eta_{\text {therm }}$ of SDC $\left(\eta_{\text {sdc }}\right)$ was obtained around $59.41 \%$, while for $\mathrm{SWH}\left(\eta_{\text {swh }}\right)$ it has been observed around $67.57 \%$ by using (1). The SDC was carrying a pressure cooker (05 litres) for cooking, which is used here for boiling/pasteurization 
of water to generate the steam (or for evaporation). Copper made pipes of $06 \mathrm{~mm}$ diameter (03 meters in length) have been used to connect the SDC with SWH through two control valves to control the hot water supply. These valves were fitted with copper made pipes (as in Figure 2). Copper tubes/pipes have been considered because of high thermal conductivity of the material. To measure the temperature of the water inside the cooker, a hole of $5 \mathrm{~mm}$ was made into the bottom side of cooker and a half-meter copper pipe was connected there (by brazing) and a thermocouple sensor was placed into the pipe and completely sealed with an adhesive of M-Seal ${ }^{\mathrm{TM}}$ (as shown in Figure 3). Another pipe of 2.5 length of the same diameter was connected to the nozzle of whistle (here, the whistle of the cooker was detached). Steam/vapor (generated by boiling/pasteurizing of the water inside the SDC) from the cooker was collected directly into a bottle (marked with a litre scale) through this pipe, where the distilled water has been obtained through condensation.

For a detailed description of the experiment, the experimentation has been carried out on a sunny day (11.04.15) on the rooftop of MIT, Moradabad. The experiments have been started at 10:00 hrs and ended at 18:00 hrs on 11.04.15. The cooker was carrying around 03 litres of prehot water supplied from SWH. The temperature of water was observed around $48^{\circ} \mathrm{C}$ in SWH as well as in SDC, at the time of starting of experiment. This temperature was noticed to be increased with increasing of $T_{\mathrm{amb}}$ (in SWH and SDC) throughout the completion of experiments. Prehot water was easily available because of "not-in-use" conditions of the water heater in summers. The system was under steady state before starting of experimentation. It has been noticed that the 03 litres of hot water was transformed into 2.21 litres distilled water within 05 hours (around 14:00 hrs) of starting of experiments. This has been confirmed through the collected distilled water into a scaled marked bottle for 02 litres and then it was reconfirmed through a (standard principle) weigh balance of $05 \mathrm{~kg}$ capacity with a reference of unit conversion (litre to kilograms). After this, the cooker again was filled by opening the control valves fitted in the supply of the water.

Figure 4 shows that the maximum temperature was attained by the water in $\operatorname{SDC}\left(93.11^{\circ} \mathrm{C}\right)$ and $\operatorname{SWH}\left(81.01^{\circ} \mathrm{C}\right)$ around 14:00 hrs. It has been observed that the system is feasible for transforming the 03 litres of the hot water into 2.21 litres of distilled water within $05 \mathrm{hrs}$ during the full sunshine hours in a day. The remaining water/steam was consumed into the atmosphere because of open losses (not considered here). After the consumption of 03-litre water in SDC at 14:00 hrs, the cooker was again filled for the same quantity of hot water through a hot water supply from SWH. Total time taken in this process was observed around 11 minutes and has not been shown in Figure 4. Now, for the duration 14:00 hrs to 18:00 hrs, it has been noticed that only 2 litres of the hot water was consumed and only 1.45 litres of distilled water can be obtained. It is because of open losses to the environment or low ambient conditions (such as high wind velocity, long duration of clouds, or dropping of $T_{\mathrm{amb}}$ ). Overall, around 3.66 litres of distilled water has been obtained from 05 litres of prehot water

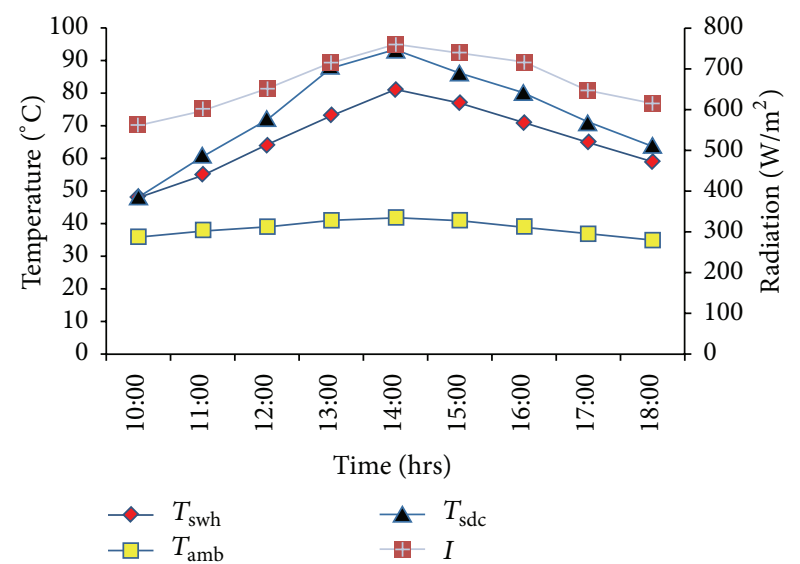

FIgURE 4: Performance curves of temperature variations during production of distilled water.

through this high rated distillation unit within 09 hours in summer season at Moradabad for the following ppm and $\mathrm{pH}$ values:

(1) ppm (hardness) values are found through the TDS meter (Model-CD600 range 10/1990) for

water (normal) of supply tank to the SWH = 290 ,

water (distilled) collected through the container $=21$;

(2) $\mathrm{pH}$ values are found through TDS meter (Model-pH 600 range 0.0 to $14.0 \mathrm{pH}$ ) for

water (normal) of the supply tank to the $\mathrm{SWH}=$ 8.9 ,

water (distilled) collected through the container $=7.7$.

Results have shown that the water is having more purity than that of previous conditions as for normal tap water. Most of the impurities have been removed and it can be used now for the desired purpose. Distilled water can also be obtained through the solar stills but not in such a high production rate. This type of arrangement (the present system) is multipurpose to obtain the hot water, to cook the food, and to produce distilled water in all the seasons for a daily schedule.

In order to perform the uncertainty analysis of experiments performed on 11.04.15, the experiments were repeated on 12.04.15. The uncertainty of some major investigated parameters is shown in Table 2. It can be clinched that the uncertainty at $96 \%$ confidence level is $\pm 0.97 \%$ for thermal efficiency of SDC and SWH.

Apart from this, as per survey carried out to observe the cooking scenario and utility management the Appendix by the five selected families, it has been noticed that the present distillation unit can be used easily for three hours/day to obtain distilled water from 10:00 hrs to $12: 00 \mathrm{hrs}$ and from 14:00 to $15: 00 \mathrm{hrs}$ for a daily productivity around 
TABLE 3: Net savings through the present system.

\begin{tabular}{|c|c|c|c|c|c|c|}
\hline Fuel (cost) & Calorific value ( $\eta \%)$ & $\begin{array}{c}\text { Saving of } \\
\text { fuel by SDC }\end{array}$ & $\begin{array}{c}\text { Savings of } \\
\text { fuel by SWH }\end{array}$ & $\begin{array}{l}\text { Saving of fuel by } \\
\text { distillation unit }\end{array}$ & $\begin{array}{l}\text { Net savings } \\
\text { annually }\end{array}$ & PBP \\
\hline LPG (IR29/ltr) & $45.56 \mathrm{MJ} / \mathrm{kg}(60 \%)$ & 388.11 ltrs & 253.44 ltrs & 176.51 ltrs & 817.55 ltrs & $1.15 \mathrm{yrs}$ \\
\hline Electricity (IR4.31/kWh) & $3.62 \mathrm{~kW} / \mathrm{h}(90 \%)$ & $2611.36 \mathrm{kWh}$ & $1705.33 \mathrm{kWh}$ & $1184.22 \mathrm{kWh}$ & $5500.91 \mathrm{kWh}$ & $1.15 \mathrm{yrs}$ \\
\hline Kerosene (IR12.75/ltr) & $38.19 \mathrm{MJ} / \mathrm{kg}(50 \%)$ & 882.84 ltrs & 576.47 ltrs & 400.31 ltrs & 1859.62 ltrs & $1.16 \mathrm{yrs}$ \\
\hline Charcoal (IR9/kg) & $29.02 \mathrm{MJ} / \mathrm{kg}(28 \%)$ & $1250.11 \mathrm{~kg}$ & $816.66 \mathrm{~kg}$ & $511.61 \mathrm{~kg}$ & $2578.38 \mathrm{~kg}$ & $1.19 \mathrm{yrs}$ \\
\hline Fuel-wood (IR5/kg) & $19.71 \mathrm{MJ} / \mathrm{kg}(17.3 \%)$ & $2251.03 \mathrm{~kg}$ & $1470 \mathrm{~kg}$ & $1020.08 \mathrm{~kg}$ & $4741.11 \mathrm{~kg}$ & $1.16 \mathrm{yrs}$ \\
\hline
\end{tabular}

of 1.15 litres/day (depends upon ambient conditions). This obtained distilled water cost around 14 IR daily. This can be estimated for a saving around $434 \mathrm{IR} / \mathrm{m}$.

\section{Economic Analysis}

The saving through the utilization of a modified high rated distillate unit in terms of money can be estimated directly through the cost of distilled water produced daily and this has been around IR 434 monthly. However, for the saving of other fuels it can be estimated by knowing the approximation consumption of the different fuels for the same purpose. Table 3 summarizes the net savings by using SDC (for cooking), SWH (for water heating), and distillation unit as an individual. PBP has been shown only on net savings of all the utilities and has been estimated by using (2). All the savings have been estimated in terms of consumption (annually) [19, 21]. It is notable that SWH was purchased for IR 20,000/- and the SDC was purchased IR 6,100/-, from NEDA, Moradabad, at a subsidy of $25 \%$. However, the total setup cost has been estimated around a sum of IR 27,500/-, for making a solar water distillation unit. By eliminating many of the mineral deposits, salts and other impurities, this easy technique provides water in a pure state. It is also notable that the present system eliminates the use of thermal heat storage mediums, which are generally used to enhance the efficiency of solar thermal systems or used for efficiently performing of the said system during the off sunshine hours or in poor ambient conditions [22].

It can be seen from Table 3 that the PBP of the whole solar distilled water unit (i.e., combination of SDC and SWH) is around 1.16 years for LPG, electricity, kerosene, and fuelwood, while it is around 1.19 years for charcoal. Besides this, a good amount of the other fuels can be saved such as LPG, (817.55 ltrs), electricity (5500 kWh), kerosene (1860 ltrs), charcoal $(2578.38 \mathrm{~kg})$, and fuel-wood $(4741.11 \mathrm{~kg})$ for the same purpose.

By using this solar distillation plant one can not only save the fuels or money but also keep the environment free from pollution and make a complete utilization of solar energy systems at a single place for obtaining some useful supplement almost at negligible cost. There is no danger of accidents or other injuries, which can be noticed, while using other highly ignited fuels, that is, burns, and so forth [23]. Another major benefit is that if the ambient conditions are good and one has a large ideal time of solar energy systems then the present system is feasible for providing around 71 ltrs (minimum) of distilled water per month, which can be supplied to nearby platforms which are battery operated invertors or for other necessities like automobiles batteries. Besides this, there is no need to purchase an additional solar still (requiring a large space for installation as well as high maintenance) to obtain distilled water or to go to the market for purchasing it.

\section{Conclusion}

The consumption of fresh water is increasing all over the world, mainly due to the population explosion as well as the rapid industrial growth. Fresh water is essential in routine life and used in agriculture as well as industry. In the present work, the efforts have been made (for solar homes) to utilize the ideal timings of a SWH and SDC in five different households by combining them into a high rated solar distilled unit. Such types of the arrangement not only utilize the maximum use of solar energy systems, but also eliminate the use of a solar still that requires a large space for installation and a higher purchase cost and also needs a high maintenance. It is also notable that the present system performs only on solar energy; no thermal heat storage material or any other type of fuel or auxiliary power has been used for high distillation rate. Apart from this, likely arrangements can cook the food, heat the water, and produce distilled water simultaneously at one platform without any conventional fuel consumption. It has been observed that the present distillation unit can be used easily three hours/day for water distillation for a daily productivity of around 1.15 litres/day (depends upon ambient conditions), simultaneously with solar cooking and water heating. This obtained distilled water cost around 14 IR daily and can save around $434 \mathrm{IR} / \mathrm{m}$. Results show that the PBP of the whole solar distilled water unit is around 1.16 years. The $\mathrm{pH}$ and ppm values were obtained as 7.7 and 21 , respectively. There has been a wide scaled adoption of distilled water in hospitals/dispensaries, schools, batteries invertors, automobiles batteries, factories, and especially solar homes.

\section{Appendix}

See Table 4. 


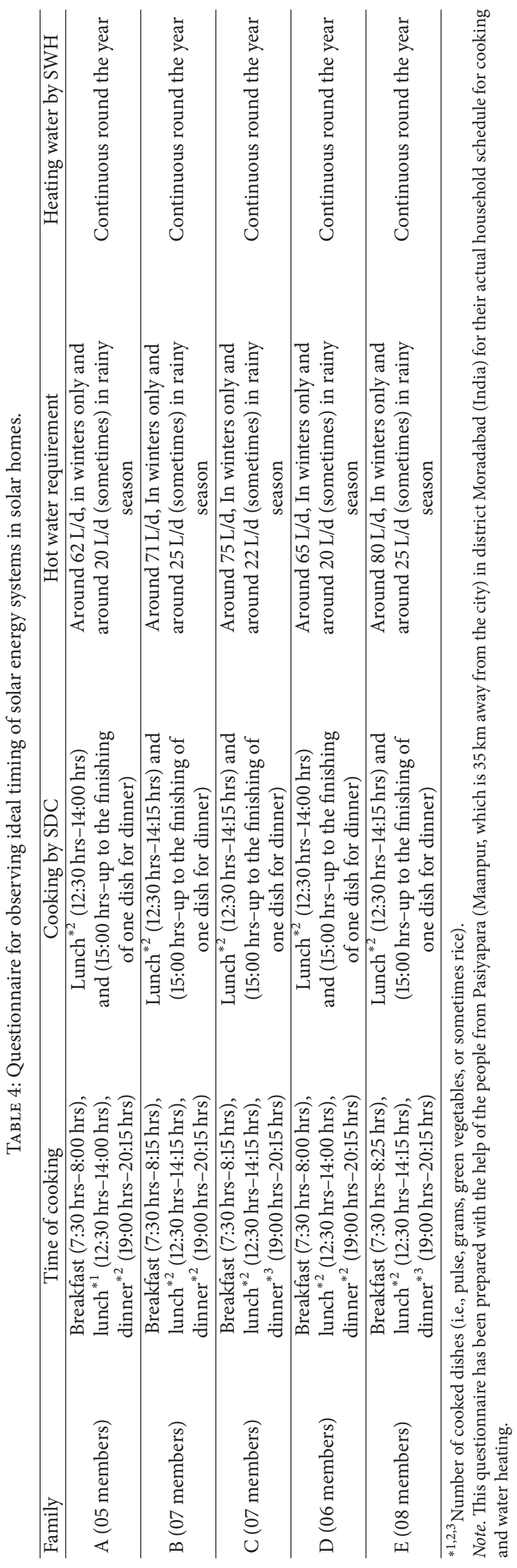




\section{Nomenclature}

SDC: Solar disc cooker

SWH: Solar water heater

NEDA: New and renewable energy development agency

PBP: $\quad$ Payback period (years)

TDS: Total dissolved solids

$\eta$ : $\quad$ Efficiency (\%)

I: $\quad$ Solar irradiance $\left(\mathrm{W} / \mathrm{m}^{2}\right)$

IR: Indian Rupees

$T, T_{\mathrm{amb}}$ : Ambient temperature $\left({ }^{\circ} \mathrm{C}\right)$

$t$ : $\quad$ Time taken (sec) in cooking as per ASAE S580 standard

$m: \quad$ Mass of substance $(\mathrm{kg})$

$C_{p}: \quad$ Specific heat of water $(\mathrm{J} / \mathrm{kg} \cdot \mathrm{K})$

A: $\quad$ Aperture area $\left(\mathrm{m}^{2}\right)$.

\section{Conflict of Interests}

The authors declare that there is no conflict of interests regarding the publication of this paper.

\section{Acknowledgments}

The authors are thankful to Shri Rampal Singh (family A), Shri Bhoorey Lal (family B), Shri Kishan Avtaar Singh (family C), Shri Brij Bhushan Kumar (family D), and Shri Mukund Bihari Lal (family E), people from the village "Pasiyapara" (Maanpur) in district Moradabad (India), for their kind support.

\section{References}

[1] M. Boukhriss, K. Zhani, and R. Ghribi, "Study of thermophysical properties of a solar desalination system using solar energy," Desalination and Water Treatment, vol. 51, no. 4-6, pp. 12901295, 2013.

[2] A. Saxena, Varun, and A. A. El-Sebaii, "A thermodynamic review of solar air heaters," Renewable and Sustainable Energy Reviews, vol. 43, pp. 863-890, 2015.

[3] K. H. Solangi, M. R. Islam, R. Saidur, N. A. Rahim, and H. Fayaz, "A review on global solar energy policy," Renewable and Sustainable Energy Reviews, vol. 15, no. 4, pp. 2149-2163, 2011.

[4] K. Zarzoum, K. Zhani, and H. B. Bacha, "Improving the design, modeling and simulation in dynamic mode of a solar still," Desalination and Water Treatment, vol. 52, no. 34-36, pp. 63046314, 2013.

[5] G. Xiao, X. Wang, M. Ni et al., "A review on solar stills for brine desalination," Applied Energy, vol. 103, pp. 642-652, 2013.

[6] T. Reddy and D. Linden, Linden's Handbook of Batteries, McGraw-Hill, 4th edition, 2010.

[7] P. Monowe, M. Masale, N. Nijegorodov, and V. Vasilenko, "A portable single-basin solar still with an external reflecting booster and an outside condenser," Desalination, vol. 280, no. 1-3, pp. 332-338, 2011.

[8] T. Arunkumar, R. Jayaprakash, D. Denkenberger et al., "An experimental study on a hemispherical solar still," Desalination, vol. 286, pp. 342-348, 2012.
[9] Y. Taamneh and M. M. Taamneh, "Performance of pyramidshaped solar still: experimental study, Desalination, vol. 291, pp. 65-68, 2012.

[10] R. V. Singh, S. Kumar, M. M. Hasan, M. E. Khan, and G. N. Tiwari, "Performance of a solar still integrated with evacuated tube collector in natural mode," Desalination, vol. 318, pp. 25-33, 2013.

[11] T. Arunkumar, D. Denkenberger, A. Ahsan, and R. Jayaprakash, "The augmentation of distillate yield by using concentrator coupled solar still with phase change material," Desalination, vol. 314, pp. 189-192, 2013.

[12] G. M. Ayoub and L. Malaeb, "Economic feasibility of a solar still desalination system with enhanced productivity," Desalination, vol. 335, no. 1, pp. 27-32, 2014.

[13] Z. M. Omara, A. E. Kabeel, and M. M. Younes, "Enhancing the stepped solar still performance using internal and external reflectors," Energy Conversion and Management, vol. 78, pp. 876881, 2014.

[14] M. R. K. Estahbanati, M. Feilizadeh, K. Jafarpur, M. Feilizadeh, and M. R. Rahimpour, "Experimental investigation of a multieffect active solar still: the effect of the number of stages," Applied Energy, vol. 137, pp. 46-55, 2015.

[15] M. A. Al-Nimr and M.-E. Dahdolan, "Modeling of a novel concentrated solar still enhanced with a porous evaporator and an internal condenser," Solar Energy, vol. 114, pp. 8-16, 2015.

[16] M. Appadurai and V. Velmurugan, "Performance analysis of fin type solar still integrated with fin type mini solar pond," Sustainable Energy Technologies and Assessments, vol. 9, pp. 3036, 2015.

[17] B.-J. Huang, T.-L. Chong, P.-H. Wu, H.-Y. Dai, and Y.-C. Kao, "Spiral multiple-effect diffusion solar still coupled with vacuum-tube collector and heat pipe," Desalination, vol. 362, pp. 74-83, 2015.

[18] A. Saxena, Varun, S. P. Pandey, and G. Srivastav, "A thermodynamic review on solar box type cookers," Renewable and Sustainable Energy Reviews, vol. 15, no. 6, pp. 3301-3318, 2011.

[19] A. Saxena and G. Srivastava, "Potential and economics of solar water heating," MIT International Journal of Mechanical Engineering, vol. 2, no. 2, pp. 97-104, 2011.

[20] Manual of Solar Dish Cooker (Akshay Urja), NEDA, Moradabad, India, 2012.

[21] T. Giglio, R. Lamberts, M. Barbosa, and M. Urbano, "A procedure for analysing energy savings in multiple small solar water heaters installed in low-income housing in Brazil," Energy Policy, vol. 72, pp. 43-55, 2014.

[22] A. Saxena, G. Srivastava, and V. Tirth, "Design and thermal performance evaluation of a novel solar air heater," Renewable Energy, vol. 77, pp. 501-511, 2015.

[23] A. Saxena, S. Lath, and N. Agarwal, "Impacts of biomass burning on living areas," TERI Information Digest on Energy \& Environment, vol. 12, no. 1, pp. 1-10, 2013. 


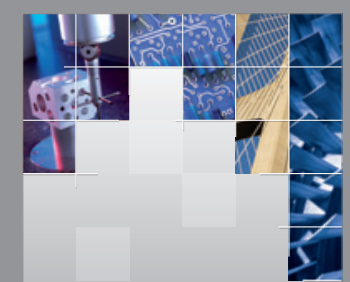

\section{Enfincering}
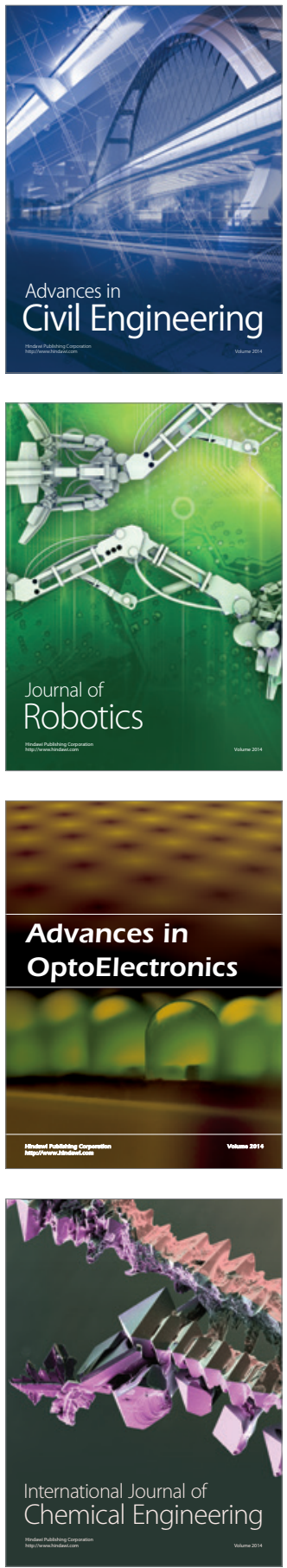

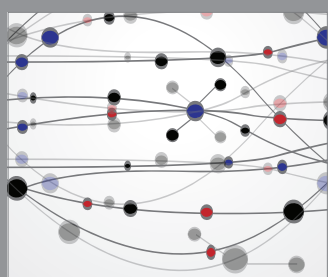

The Scientific World Journal

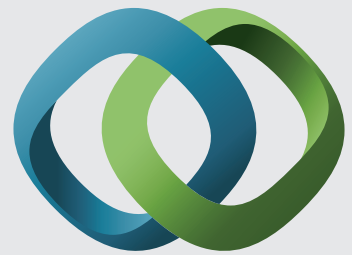

\section{Hindawi}

Submit your manuscripts at

http://www.hindawi.com
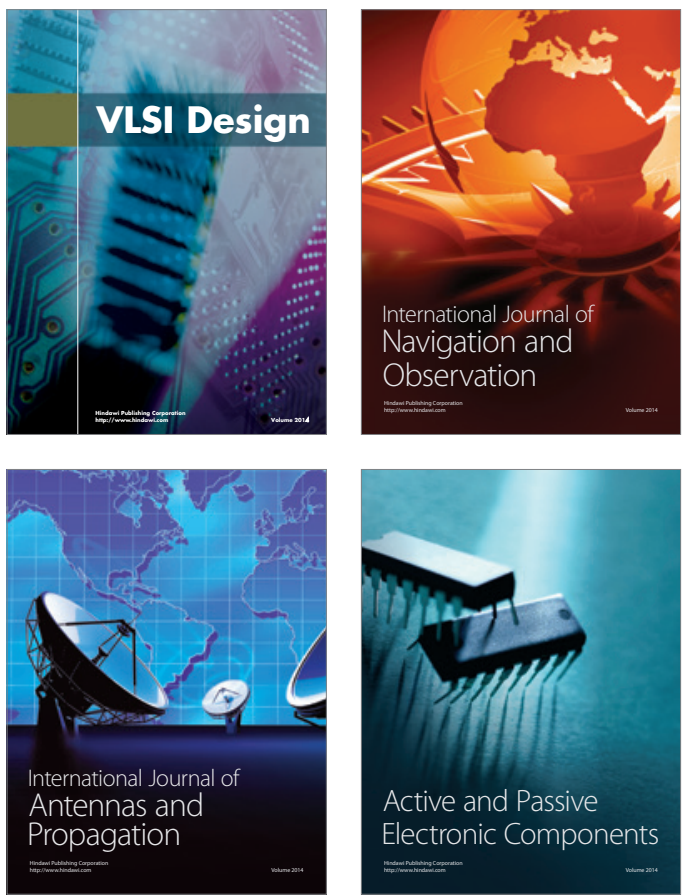
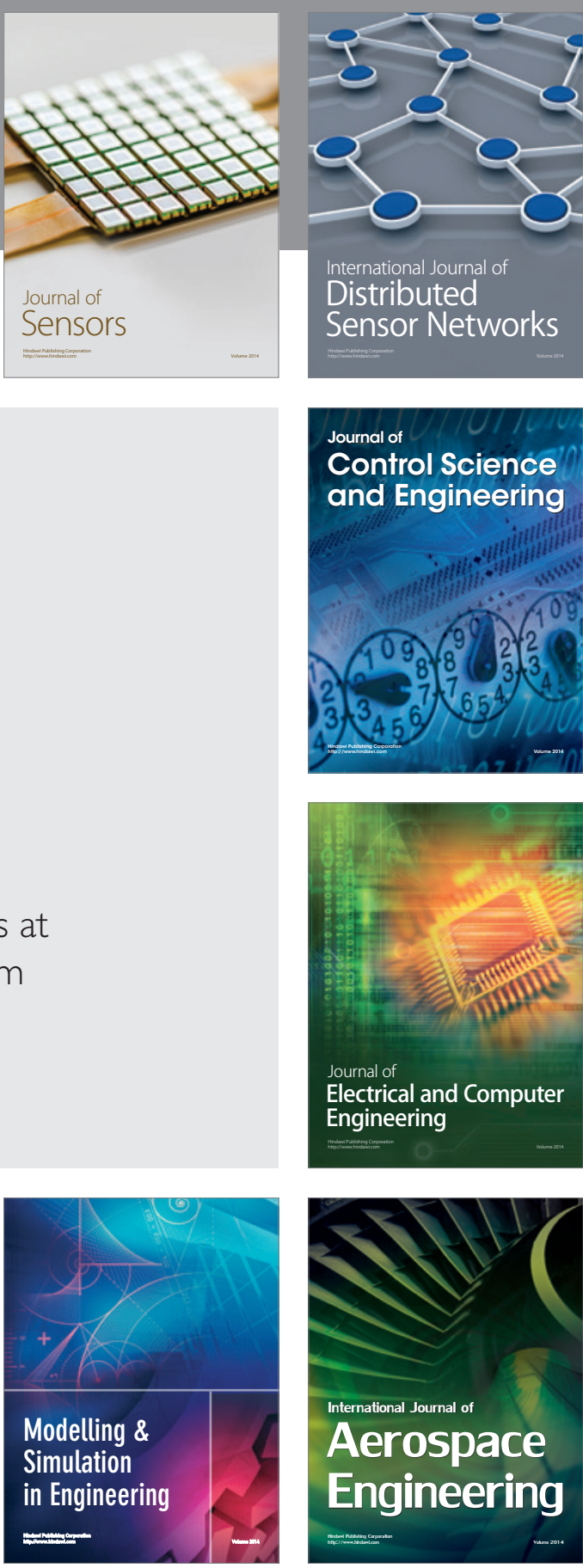

International Journal of

Distributed

Sensor Networks

Journal of

Control Science

and Engineering
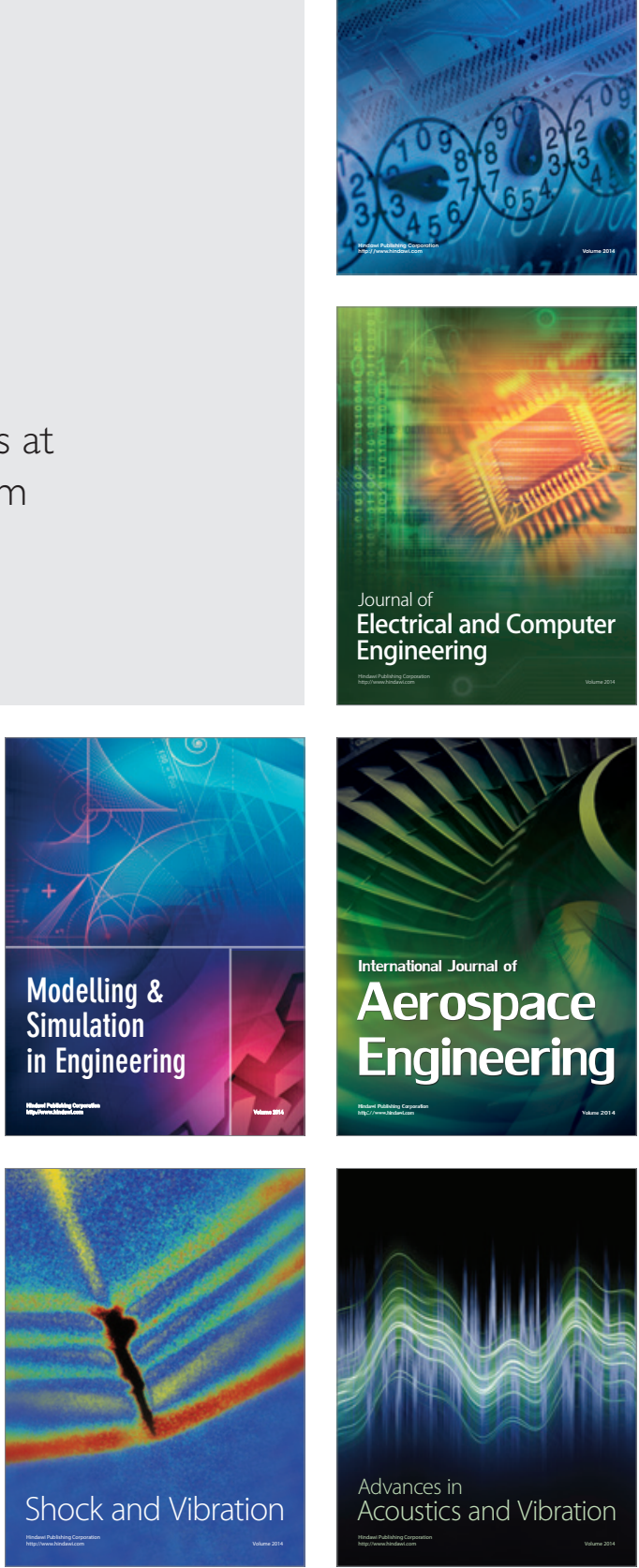